\title{
Mechanical properties of copper slag waste based CLSM mixtures
}

\author{
Roman Jaskulski ${ }^{1}$, Wojciech Kubissa ${ }^{2}$ \\ Faculty of Civil Engineering, Mechanics and Petrochemistry, Warsaw University of Technology, Plock, Poland \\ E-mail: ${ }^{1}$ Roman.Jaskulski@pw.edu.pl (corresponding author)
}

\begin{abstract}
The article presents the results of investigations of the compressive strength of controlled low-strength materials (CLSM) prepared with the use of copper slag waste as a filler. Eighteen mixtures were made of which part with sole copper slag waste, part with sand which served as reference and mixtures in which half of the filler was sand and half the copper slag waste. Part of them was prepared with $60 \mathrm{~kg} / \mathrm{m}^{3}$ of cement and another part with $40 \mathrm{~kg} / \mathrm{m}^{3}$ of cement. As a supplementary binder conventional fly ash was used. The aim was to recognie the feasibility of this type of material using copper slag waste as filler. Compressive strength tests were performed on the specimens in form of $40 \times 40 \times 160 \mathrm{~mm}$ bars. The tests showed that after meeting certain conditions regarding the composition of the mixture, the copper slag waste can be used as a filler in CLSM. The compressive strength values after 180 days not exceeded 1.60 MPa which is a very good result for this kind of material.
\end{abstract}

Keywords: constrolled low-strength materials, copper slag waste, compressive strength.

\section{Introduction}

Controled low strength material (CLSM) is a self-compacting cementitious composite, mainly used instead of compacted soil. It has been widely used for several decades in many countries (United States, Canada, Great Britain, France and others), and its use offers numerous benefits.

The term CLSM is used to describe mixtures with cementitious binder, containing various components, with different applications, the compression strength of which, as defined in (ACI, 2018), does not exceed 8.3 MPa. In most applications, this strength should not exceed $2.1 \mathrm{MPa}$ to ensure relatively easy removal of the material if necessary (ACI, 2005). CLSM has many advantages described in detail in the literature, e.g. (ACI, 2005; Howard \& Hitch 1998; Hitch, Howard, \& Baas, 2004; Karbownik, 2012). Among other things, it enables the use of various waste materials, which reduce cost and is beneficial for the environment. Usually local materials are used to prepare it to make it cheap and easy available.

CLSM mixes can be tailored to meet specific requirements: compressive strength, consistency and other features, including high or low thermal conductivity, relevant for some special applications. CLSM usually reduces the costs of works compared to traditional compaction of soils, as it does not require compactors or rollers, does not require compaction control during laying and can be laid almost independently of the weather.

Because CLSM is self-leveling and does not require compaction or spreading, it is easy to use in tight spaces or with limited access, where placing and compacting traditional filling is difficult or impossible at all. It also allows you to avoid the emission of vibrations generated during compaction of traditional backfills, which is especially important in cities and around historic buildings. Compression strength within the upper limit of $8.3 \mathrm{MPa}$ allows the material to be used where there is no need to remove it in the future, such as fillings and structural subsoils under buildings and structures (Alizadeh, Helwany, Ghorbanpoor, \& Sobolev, 2014). CLSM is a good material for covering pipes, electrical wires, telephone lines and other infrastructure (Ling, Kaliyavaradhan, \& Poon, 2018). It is also used as permanent foundations for pavements or backfills for filling excavations. Low density CLSM, i.e. blends with the addition of a foaming agent, are used as anticorrosion and thermal insulation. CLSM should not be considered a type of low-strength concrete, but rather like self-compacting material, used as an alternative to compacted soils. CLSM can also not be confused with cement stabilized soils, described in (ACI, 2009).

In addition to the above-mentioned advantages associated with the use of CLSM, this composite also has some drawbacks that should be taken into account at the stage of material selection for a given application. Generally, CLSM mixes are not frostproof, resistant to abrasion, erosion or aggressive chemical agents (ACI, 2005).

(C) 2019 Authors. Published by VGTU Press. This is an open-access article distributed under the terms of the Creative Commons Attribution (http://creativecommons.org/licenses/by/4.0/) License, which permits unrestricted use, distribution, and reproduction in any medium, provided the original author and source are credited. 
CLSM is a material used in many countries, especially in the USA, for several decades. One of the first applications took place in 1964 as pipe cover in the Canadian River Aqueduct Project in Texas. A 40\% reduction in costs and a significant acceleration of work were obtained compared to conventional material requiring compaction (Howard \& Hitch, 1998). In 1984, the ACI 229 committee was established under the name "Controlled Low Strength Materials (CLSM)". In 1994, a report entitled "Controlled Low Strength Materials (CLSM)" was published, which was widely disseminated. The next version of the report was created in 1999 and was revised in 2005. There are currently 5 ASTM standards describing testing of CLSM materials (ASTM, 2016a; ASTM, 2016b; ASTM, 2016c; ASTM, 2016d; ASTM, 2017).

Typical CLSM mixtures contain water, cement, fly ash or similar ingredient and fine or coarse aggregate or a mixture of different aggregates. The most basic mixtures contain only water, cement and fly ash. Selection of materials should result from their availability, price, specificity of the given application (eg. maximum aggregate grain size due to the possibility of using the pump) and the required properties of the resulting material, especially workability, durability, ease of removal and density (ACI, 2005). Currently, research is still being carried out on the use of various waste products in the production of CLSM (Shon, Mukhopadhyay, Saylak, Zollinger, \& Mejeoumov, 2010; Naganathan, Razak, \& Hamid, 2012; Zhen, Zhou, T. Zhao, \& Y. Zhao, 2012; Sheen, Huang, Wang, \& Le, 2014; Nataraja \& Nalanda, 2008; Taha, Alnuaimi, Al-Jabri, \& Al-Harthy, 2007; Katz \& Kovler, 2004; Le \& Nguyen, 2016; Wang et al., 2018). One of them may be copper slag waste from surface blast cleaning. As a CLSM mixtures filler, it can replace sand, from which it has a slightly higher density, but at the same time has lower thermal conductivity (Jaskulski, Reiterman, \& Kubissa, 2017). CLSM with such a component is a material suitable for backfilling infrastructure that requires increased thermal insulation, primarily heat pipes and underground pipelines transporting process steam. Increasing the insulation of the surrounding backfill allows you to reduce heat losses to the ground and increase their efficiency.

In Poland, CLSM is not very widely used which is, among others, a result of regulations regarding the treatment of industrial waste, which includes fly ashes, as well as the need to obtain technical approvals for any change in the composition or materials used. An additional difficulty in the case of waste of copper slag results from its increased radioactivity (Keller, Hoffmann, \& Feigenspan, 2001). However, when using this material as a CSLM filler, it is possible to select the proportion of ingredients so that the radiation requirements are met.

This paper presents the results of research in order to identify the feasibility CLSM mixtures based on copper slag waste. The preliminary stage of the research, was aimed at checking what strength can be obtained by replacing partially or completely the sand with a copper slag waste and how the strength of the material so prepared varies over time. The aim was to obtain mixtures with strength in the range above $0.3 \mathrm{MPa}$ and below $2.1 \mathrm{MPa}$.

\section{Materials and performed tests}

\section{Composition of materials}

The Portland blnded cement CEM II/B-V 32.5N - LH/HSR/NA, conventional fly ash, quartz sand and copper slag waste were used for preparing CLSM. The latter material is a remnant after using copper slag in the surface blast cleaning procedure. Tap water was used as the mixing water.

Two groups of CLSM were prepared. The first group consisted of 12 mixtures. They were prepared with use of $60 \mathrm{~kg}$ of cement for $1 \mathrm{~m}^{3}$ of material. These mixtures were prepared in order to recognize the feasibility of this type of material using copper slag waste. From the prepared 12 series of materials, 4 subgroups were separated with fly ash amounting to $200,400,600$ and $800 \mathrm{~kg} / \mathrm{m}^{3}$ respectively. In each of these subgroups, CLSM were differentiated in terms of aggregate used. Quartz sand, copper slag waste and a mixture of both materials in equal volume proportions were used. The amount of water in all cases was taken indicatively according to the recipes presented in the article (Kubissa, 2013). Recipes of materials from this group are presented in Table 1.

Table 1. Recipes of the first group of CLSM $\left[\mathrm{kg} / \mathrm{m}^{3}\right]$

\begin{tabular}{|l|c|c|c|c|c|c|c|c|c|c|c|c|}
\hline & C2S & C2SC & C2C & C4S & C4SC & C4C & C6S & C6SC & C6C & C8S & C8SC & C8C \\
\hline Cement & 60 & 60 & 60 & 60 & 60 & 60 & 60 & 60 & 60 & 60 & 60 & 60 \\
\hline Quartz sand & 1369 & 684 & - & 1139 & 569 & - & 815 & 408 & - & 352 & 176 & - \\
\hline Copper slag waste & - & 780 & 1560 & - & 644 & 1289 & - & 461 & 923 & - & 199 & 399 \\
\hline Fly ash & 199 & 199 & 199 & 397 & 397 & 397 & 596 & 596 & 596 & 795 & 795 & 795 \\
\hline Water & 356 & 356 & 356 & 341 & 341 & 341 & 358 & 358 & 358 & 427 & 427 & 427 \\
\hline
\end{tabular}

The second group consisted of 6 materials. The CLSM with the smallest and largest amount of fly ash was abandoned. A smaller amount of cement was also used: $40 \mathrm{~kg} / \mathrm{m}^{3}$. Additionally, the pre-set amount of water was verified experimentally by testing the flow of the mixture. If it was smaller than $200 \mathrm{~mm}$, tested in accordance with 
ASTM D6103 D6103M - 17, then a mixture was made again with more water and the optimal composition was iteratively selected. The recipes of CLSM from the second group can be found in Table 2. The amount of water given in it is established as a result of iterative modification of preliminary recipes.

Table 2. Recipes of the second group of CLSM

\begin{tabular}{|l|c|c|c|c|c|c|}
\hline & D4S & D4SC & D4C & D6S & D6SC & D6C \\
\hline Cement & 40 & 40 & 40 & 40 & 40 & 40 \\
\hline Quartz sand & 1139 & 569 & 0 & 815 & 408 & 0 \\
\hline Copper slag waste & 0 & 644 & 1289 & 0 & 461 & 923 \\
\hline Fly ash & 411 & 411 & 411 & 610 & 610 & 610 \\
\hline Water & 307 & 272 & 307 & 252 & 287 & 268 \\
\hline
\end{tabular}

A plastic bucket with a capacity of $20 \mathrm{dm}^{3}$ and an electric agitator were used to prepare the mixtures. The dosing was started with a filler, to which cement was added, and finally fly ash. After thorough mixing of the dry ingredients, water was added and mixed until a homogeneous mixture was obtained. The material was then poured into oiled moulds which were stored in laboratory conditions with temperature $22 \pm 2{ }^{\circ} \mathrm{C}$ and relative humidity about $50-60 \%$.

\section{Compressive strength test}

Specimens in the form of bars measuring $40 \times 40 \times 160 \mathrm{~mm}$ were prepared for strength tests. Six samples were made in each series. They were demoulded $2-3$ days after forming, and then stored in containers in which the relative humidity was maintained above $95 \%$.

Before testing the compressive strength, the bars were broken into two parts around the center of their span. In each series, 12 compressive strength tests were planned at three dates: after 7, 28 and 90 days (first group of CLSM) or 180 days (second group of CLSM). Due to the low strength of the obtained materials, some bars were damaged before testing, hence in some cases the number of tested specimens is smaller.

Specimens were tested on a strength machine with a load range of up to $100 \mathrm{kN}$. The rate of increase in the load was regulated by the speed of moving the movable press element and amounted to $1.5 \mathrm{~mm} / \mathrm{min}$.

\section{Results and discussion}

\section{General remarks}

According to the ACI (ACI, 2005) report, CLSM with a compressive strength of 0.3 to $0.7 \mathrm{MPa}$ have a bearing capacity of well compacted soil. It is assumed that up to $0.3 \mathrm{MPa}$ of strength CLSM can be removed from the excavation manually. From 0.3 to $1.4 \mathrm{MPa}$ it can be removed with back-hoe, and in the case of CLSM made with use of fine aggregate only or with sole fly ash, the upper limit increases to the value of $2.1 \mathrm{MPa}$. The aim of the presented research was to determine whether, given the assumptions regarding the composition, CLSM can be obtained, the strength of which is within the given limits, i.e. at least $0.3 \mathrm{MPa}$ and not more than $2.1 \mathrm{MPa}$.

\section{First group of CLSM mixtures}

The results of the compressive strength test of the first CLSM group after 7, 28 and 90 days are shown in Table 3.

Table 3. Compressive strength test results of the first group of CLSM

\begin{tabular}{|c|c|c|c|c|c|c|c|c|c|c|c|c|c|}
\hline \multirow{2}{*}{\multicolumn{2}{|c|}{ Compressive strength after: }} & \multicolumn{12}{|c|}{ CLSM series } \\
\hline & & $\mathrm{C} 2 \mathrm{~S}$ & $\mathrm{C} 2 \mathrm{SC}$ & $\mathrm{C} 2 \mathrm{C}$ & $\mathrm{C} 4 \mathrm{~S}$ & $\mathrm{C} 4 \mathrm{SC}$ & $\mathrm{C} 4 \mathrm{C}$ & C6S & C6SC & $\mathrm{C} 6 \mathrm{C}$ & C8S & $\mathrm{C} 8 \mathrm{SC}$ & $\mathrm{C} 8 \mathrm{C}$ \\
\hline \multirow{3}{*}{7 days } & mean $[\mathrm{MPa}]$ & 0.41 & 0.32 & 0.05 & 0.48 & 0.43 & 0.42 & 0.54 & 0.47 & 0.37 & 0.31 & 0.37 & 0.30 \\
\hline & $\mathrm{SD}[\mathrm{MPa}]$ & 0.03 & 0.03 & 0.01 & 0.02 & 0.03 & 0.02 & 0.03 & 0.03 & 0.02 & 0.03 & 0.03 & 0.01 \\
\hline & $\mathrm{n}[-]$ & 9 & 12 & 9 & 11 & 12 & 11 & 12 & 12 & 12 & 10 & 11 & 10 \\
\hline \multirow{3}{*}{28 days } & mean $[\mathrm{MPa}]$ & 1.15 & 0.73 & 0.06 & 0.78 & 0.81 & 0.86 & 1.01 & 0.77 & 0.66 & 0.54 & 0.57 & 0.50 \\
\hline & $\mathrm{SD}[\mathrm{MPa}]$ & 0.06 & 0.09 & 0.01 & 0.02 & 0.04 & 0.03 & 0.06 & 0.04 & 0.02 & 0.03 & 0.06 & 0.02 \\
\hline & $\mathrm{n}[-]$ & 11 & 12 & 12 & 12 & 12 & 10 & 11 & 12 & 8 & 12 & 12 & 11 \\
\hline \multirow{3}{*}{90 days } & mean $[\mathrm{MPa}]$ & 1.59 & 1.08 & - & 1.21 & 1.07 & 1.21 & 1.15 & 1.05 & 0.99 & 0.71 & 0.78 & 0.67 \\
\hline & $\mathrm{SD}[\mathrm{MPa}]$ & 0.10 & 0.14 & - & 0.02 & 0.03 & 0.05 & 0.07 & 0.04 & 0.06 & 0.02 & 0.02 & 0.03 \\
\hline & $\mathrm{n}[-]$ & 11 & 12 & - & 11 & 11 & 12 & 12 & 12 & 12 & 12 & 12 & 12 \\
\hline
\end{tabular}


Apart from the $\mathrm{C} 2 \mathrm{C}$ series, in which $200 \mathrm{~kg} / \mathrm{m}^{3}$ of fly ash and sole copper slag waste were used, we managed to obtain materials which compressive strength after 7 days reached the lower assumed limit, and after 180 days it did not exceed the upper limit. The $\mathrm{C} 2 \mathrm{C}$ series has achieved very low strengths probably due to the small amount of fly ash and the simultaneous replacement of all sand by copper slag waste. In this case, it was not possible to test the strength after 90 days due to very numerous damages of the specimens.

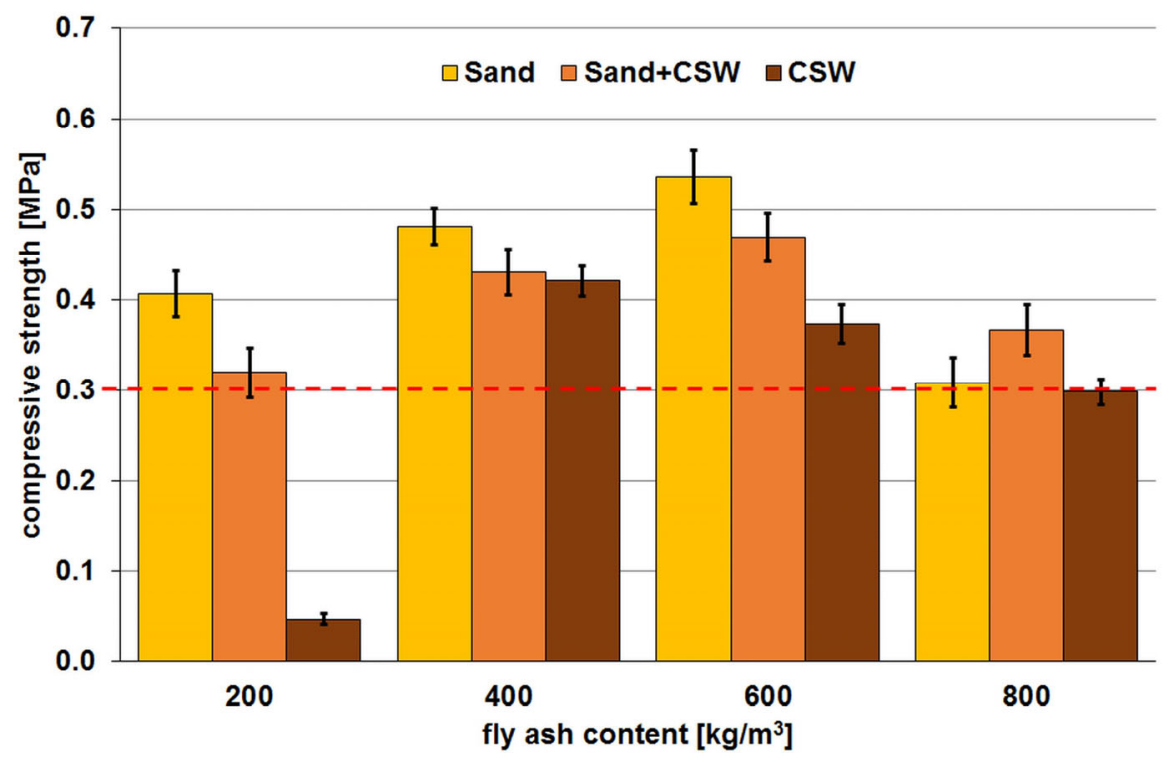

Figure 1. Compressive strength of the first group of CLSM after 7 days (source: own research)

The compressive strength plots of the first group CLSM tested at different ages are shown in Figures 1 and 2. The red dashed line indicates the minimum required compressive strength value $(0.3 \mathrm{MPa})$. In the case of the test strength after 7 days (Figure 1), two trends can be observed. The first one is the increase in strength together with the increase in the fly ash content in the material, from this trend CLSM mixtures with fly ash content of $800 \mathrm{~kg} / \mathrm{m}^{3}$ are falling out. The second trend is the decrease in strength along with the decrease in the amount of sand in the mix. For this trend, the strength of C8SC series is an exception.

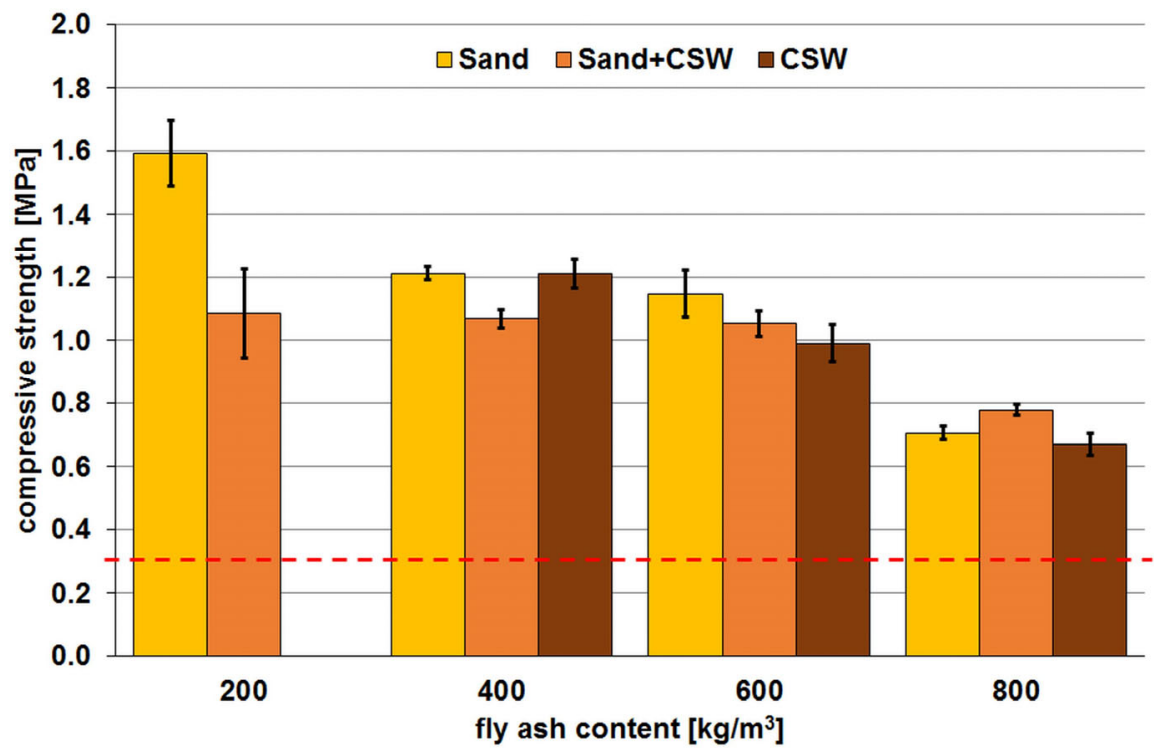

Figure 2. Compressive strength of the first group of CLSM after 90 days (source: own research)

The results of compressive strength test performed after 90 days are shown in Figure 2. They follow the same trends as the results after 7 days, although the differences between the results after 90 days are lower, and the trends themselves are slightly less pronounced. The increase in the value of CLSM strength with copper slag waste is noticeable in comparison with the remaining mixes. The increase in strength over a longer period of time is usually associated 
with the pozzolanic reaction. It suggests that the copper slag waste may be a material that undergoes such a reaction to some extent.

\section{Second group of CLSM mixtures}

The results of the compressive strength results of the second group of CLSM after 7,28 and 180 days are shown in Table 4. The mixtures from this group was tested after 180 days to ensure that even after so long period the maximum assessed compressive strength value is not exceeded.

Table 4. Compressive strength test results of the second group of CLSM

\begin{tabular}{|c|c|c|c|c|c|c|c|}
\hline \multirow{2}{*}{\multicolumn{2}{|c|}{ Compressive strength after: }} & \multicolumn{6}{|c|}{ CLSM series } \\
\hline & & \multirow{2}{*}{$\frac{\mathrm{D} 4 \mathrm{~S}}{0.32}$} & \multirow{2}{*}{$\frac{\mathrm{D} 4 \mathrm{SC}}{0.30}$} & \multirow{2}{*}{$\frac{\mathrm{D} 4 \mathrm{C}}{0.07}$} & \multirow{2}{*}{$\frac{\text { D6S }}{0.82}$} & \multirow{2}{*}{$\frac{\text { D6SC }}{0.73}$} & \multirow{2}{*}{$\frac{\mathrm{D} 6 \mathrm{C}}{0.56}$} \\
\hline \multirow{3}{*}{7 days } & mean $[\mathrm{MPa}]$ & & & & & & \\
\hline & $\mathrm{SD}[\mathrm{MPa}]$ & 0.01 & 0.02 & 0.00 & 0.03 & 0.05 & 0.01 \\
\hline & $\mathrm{n}[-]$ & 12 & 12 & 12 & 12 & 12 & 12 \\
\hline \multirow{3}{*}{28 days } & mean $[\mathrm{MPa}]$ & 0.44 & 0.50 & 0.33 & 1.05 & 1.08 & 0.95 \\
\hline & $\mathrm{SD}[\mathrm{MPa}]$ & 0.03 & 0.03 & 0.08 & 0.04 & 0.04 & 0.04 \\
\hline & $\mathrm{n}[-]$ & 12 & 12 & 12 & 11 & 12 & 12 \\
\hline \multirow{3}{*}{180 days } & mean $[\mathrm{MPa}]$ & 0.80 & 0.97 & 0.44 & 1.45 & 1.50 & 2.05 \\
\hline & $\mathrm{SD}[\mathrm{MPa}]$ & 0.08 & 0.07 & 0.00 & 0.49 & 0.09 & 0.08 \\
\hline & $\mathrm{n}[-]$ & 6 & 12 & 12 & 4 & 12 & 11 \\
\hline
\end{tabular}

As in the case of the first group of mixes, also CLSMs prepared in the second stage of research achieved compressive strength values within the assumed limits. The only exception is the D4C mixture, which after 7 days has reached a compressive strength of $0.07 \mathrm{MPa}$. However, after 28 and 180 days its strength exceeded the assumed lower limit of strength or $0.3 \mathrm{MPa}$. A smaller amount of cement used in the preparing of mixes of this group was reflected in the lower compressive strength values after 7 and 28 days.

After 180 days CLSM of the second group made using $400 \mathrm{~kg} / \mathrm{m}^{3}$ of fly ash are characterized by still lower compressive strength than mixes from the first group with the same amount of fly ash after 90 days. However, in the case of mixes with $600 \mathrm{~kg} / \mathrm{m}^{3}$ of fly ash, there is a clear increase in compressive strength of the CLSM of the second group after 180 days in comparison with those of the first group tested after 90 days. The highest strength after 180 days was achieved by CLSM mixes made without sand. This may suggest a synergistic effect of using higher amount of fly ash with copper slag waste.

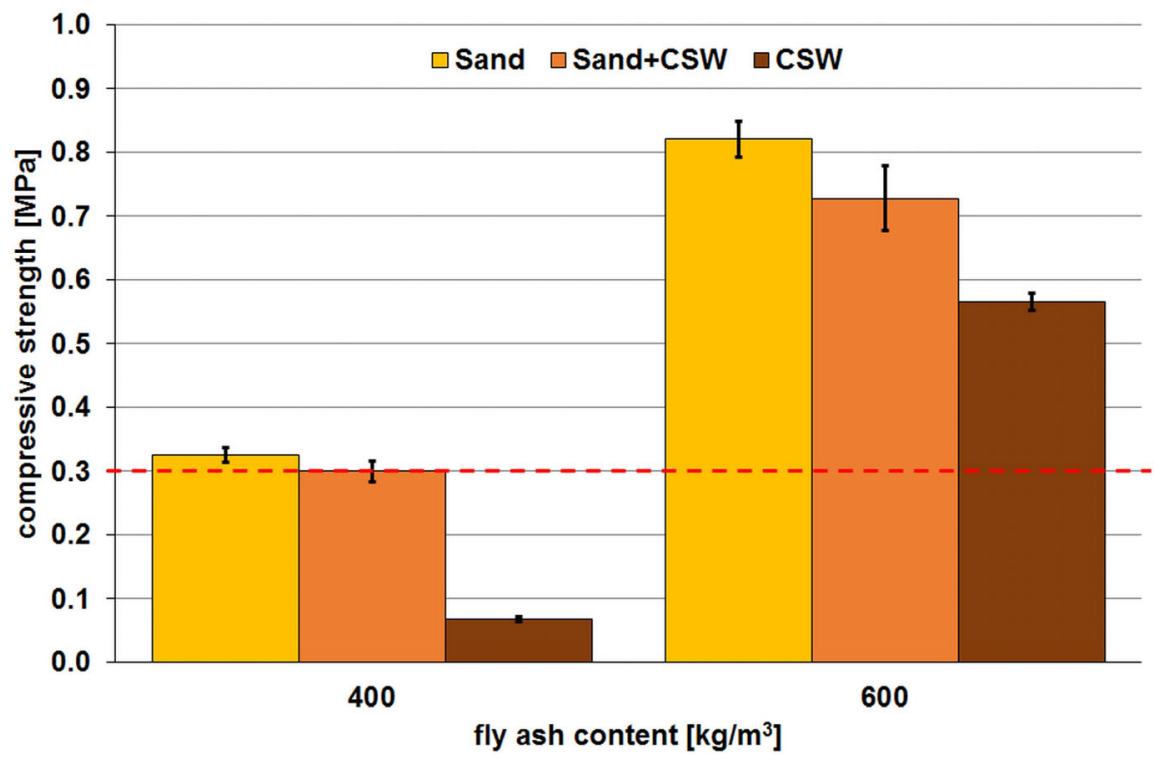

Figure 3. Compressive strength of the second group of CLSM after 7 days (source: own research)

Figures 3 and 4 present graphs depicting the results of compressive strength tests of CLSM after 7 days (Figure 3) and after 180 days (Figure 4). The red dashed lines indicate the required compressive strength limits (lower $-0.3 \mathrm{MPa}$ 
and upper - 2.1 MPa). The analysis of the graphs indicates a change in the mutual proportions of the compression strength values of CLSM mixtures over time. After 180 days, the relative increase in the strength of CLSM is greatest in the case of mixtures without sand, and the smallest in the case of mixtures without copper slag waste regardless of the amount of fly ash used. However, in the case of an absolute increase in strength, such a pattern appears only in the case of mixes made of $600 \mathrm{~kg} / \mathrm{m}^{3}$ of fly ash. In the case of CLSM mixtures made of $400 \mathrm{~kg} / \mathrm{m}^{3}$ of fly ash, the D4C mixture prepared without the use of sand does not match the pattern.

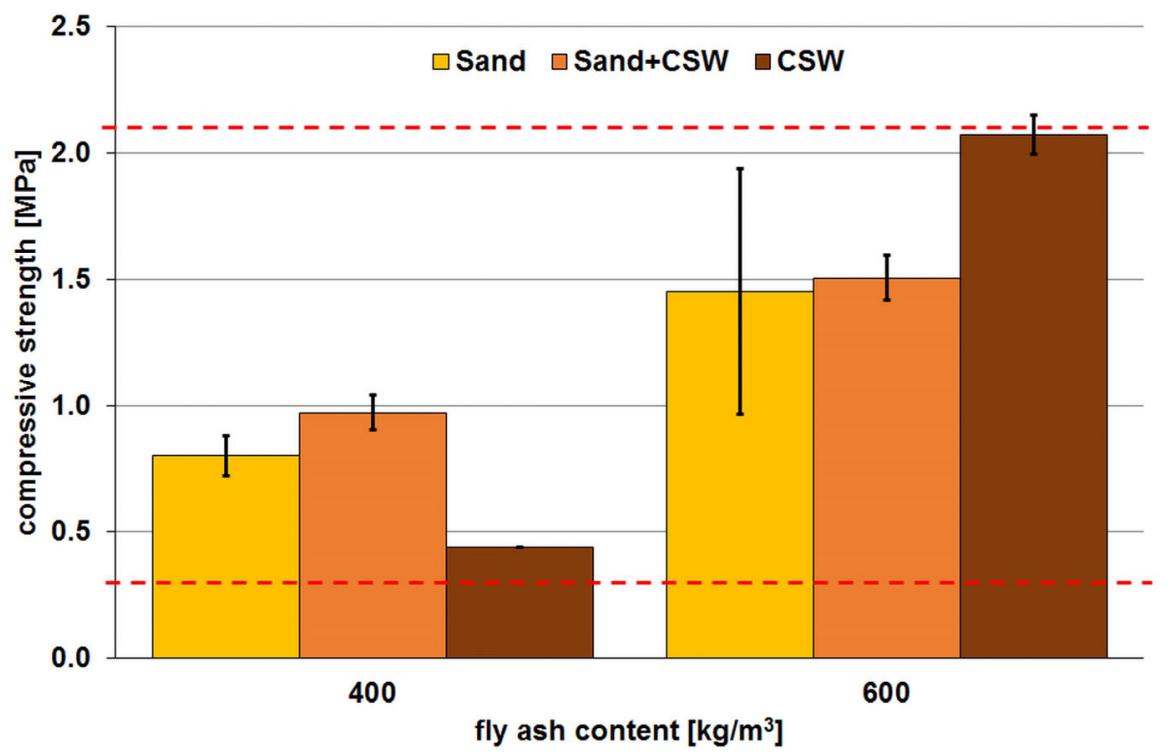

Figure 4. Compressive strength of the second group of CLSM after 180 days (source: own research)

\section{Conclusions}

The performed research allowed to formulate the following conclusions:

1. Higher increase of compressive strength in a longer time (after 90 and 180 days) showed mixtures with copper slag waste than with sand only. This indicates some pozzolanic activity of copper slag waste.

2. The optimal amount of fly ash in the blends was $600 \mathrm{~kg} / \mathrm{m}^{3}$. When using $60 \mathrm{~kg} / \mathrm{m}^{3}$ of cement, $400 \mathrm{~kg} / \mathrm{m}^{3} \mathrm{can}$ also be considered an optimal fly ash content. The tests confirmed that too much fly ash content worsens the strength properties of CLSM mixes.

3. Mixes with the smallest amount of fly ash $\left(200 \mathrm{~kg} / \mathrm{m}^{3}\right)$ did not reach the lower limit of strength after 28 days despite the use of $60 \mathrm{~kg} / \mathrm{m}^{3}$ of cement.

4. The use of CEM II/B-V cement (instead of usually used CEM I cement) allowed to obtain CSLM with the optimum composition for applications where it may be necessary to remove hardened material from the excavation without the possibility of using heavy equipment. The compressive strength of such mixtures even after 180 days did not exceed 2.1 MPa.

\section{Acknowledgements}

Authors wish to thank Mr. Paweł Wojewódzki for help in preparing specimens and conducting tests.

\section{References}

ACI. (2005). ACI 229R controlled low-strength materials. American Concrete Institute, Farmington Hills.

ACI. (2009). ACI 230.1R Report on soil cement. American Concrete Institute, Farmington Hills.

ACI. (2018). CT-18: ACI concrete terminology. American Concrete Institute, Farmington Hills.

Alizadeh, V., Helwany, S., Ghorbanpoor, A., \& Sobolev, K. (2014). Design and application of controlled low strength materials as a structural fill. Construction and Building Materials, 53, 425-431. https://doi.org/10.1016/j.conbuildmat.2013.12.006

ASTM. (2016a). ASTM D4832 - 16e Standard test method for preparation and testing of controlled low strength material (CLSM) test cylinders. ASTM International, West Conshohocken.

ASTM. (2016b). ASTM D5971/D5971M-16 standard practice for sampling freshly mixed controlled low-strength material. ASTM International, West Conshohocken. 
ASTM. (2016c). ASTM D6023 - 16 standard test method for density (Unit Weight), yield, cement content, and air content (Gravimetric) of controlled low-strength material (CLSM). ASTM International, West Conshohocken.

ASTM. (2016d). ASTM D6024/D6024M - 16 standard test method for ball drop on controlled low strength material (CLSM) to determine suitability for load application. ASTM International, West Conshohocken.

ASTM. (2017). ASTM D6103/D6103M - 17 standard test method for flow consistency of controlled low strength material (CLSM). ASTM International, West Conshohocken.

Hitch, J. L., Howard, A. K., \& Baas, W. P. (Eds.). (2004). Innovations in controlled low-strength material (Flowable Fill). ASTM International, West Conshohocken. https://doi.org/10.1520/STP1459-EB

Howard, A. K., \& Hitch, J. L. (Eds.). (1998). The design and application of controlled low-strength materials (Flowable Fill). ASTM International, West Conshohocken. https://doi.org/10.1520/STP1331-EB

Jaskulski, R., Reiterman, P., \& Kubissa, W. (2017). Investigation of thermal properties of concrete with recycled aggregate and concrete with copper slag and supplementary cementing materials. In I. Hager (Ed.), Energy efficient, sustainable building materials and products (pp. 283-302). Cracow: Cracow University of Technology.

Karbownik, P. (2012). Zagęszczony grunt bez wibracji czyli mieszanki wypełniające GRUNTON®. In III Konferencja NaukowoTechniczna Awarie, Remonty, Monitoring Sieci Wod-Kan. Cedzyna, Poland.

Katz, A., \& Kovler, K. (2004). Utilization of industrial by-products for the production of Controlled Low Strength Materials (CLSM). Waste Management, 24(5), 501-512. https://doi.org/10.1016/S0956-053X(03)00134-X

Keller, G., Hoffmann, B., \& Feigenspan, T. (2001). Radon permeability and radon exhalation of building materials. Science of the Total Environment, 272(1-3), 85-89. https://doi.org/10.1016/S0048-9697(01)00669-6

Kubissa, W. (2013). Samozagęszczające się materiały małej wytrzymałości. Inżynieria i Budownictwo, 69(10), 525-529.

Le, D.-H., \& Nguyen, K.-H. (2016). An Assessment of eco-friendly controlled low-strength material. Procedia Engineering, 142, 260-267. https://doi.org/10.1016/j.proeng.2016.02.040

Ling, T.-C., Kaliyavaradhan, S. K., \& Poon, C. S. (2018). Global perspective on application of controlled low-strength material (CLSM) for trench backfilling - An overview. Construction and Building Materials, 158, 535-548. https://doi.org/10.1016/j.conbuildmat.2017.10.050

Naganathan, S., Razak, H. A., \& Hamid, S. N. A. (2012). Properties of controlled low-strength material made using industrial waste incineration bottom ash and quarry dust. Materials \& Design, 33, 56-63. https://doi.org/10.1016/j.matdes.2011.07.014

Nataraja, M. C., \& Nalanda, Y. (2008). Performance of industrial by-products in controlled low-strength materials (CLSM). Waste Management, 28(7), 1168-1181. https://doi.org/10.1016/j.wasman.2007.03.030

Sheen, Y.-N., Huang, L.-J., Wang, H.-Y., \& Le, D.-H. (2014). Experimental study and strength formulation of soil-based controlled low-strength material containing stainless steel reducing slag. Construction and Building Materials, 54, 1-9. https://doi.org/10.1016/j.conbuildmat.2013.12.049

Shon, C.-S., Mukhopadhyay, A. K., Saylak, D., Zollinger, D. G., \& Mejeoumov, G. G. (2010). Potential use of stockpiled circulating fluidized bed combustion ashes in controlled low strength material (CLSM) mixture. Construction and Building Materials, 24(5), 839-847. https://doi.org/10.1016/j.conbuildmat.2009.10.022

Taha, R. A., Alnuaimi, A. S., Al-Jabri, K. S., \& Al-Harthy, A. S. (2007). Evaluation of controlled low strength materials containing industrial by-products. Building and Environment, 42(9), 3366-3372. https://doi.org/10.1016/j.buildenv.2006.07.028

Wang, L., Fuliao, Z., Xiaoliang, F., Daniel, C. W. T., Chi Sun, P., Zhen, L., \& Kitae, B. (2018). A novel type of controlled low strength material derived from alum sludge and green materials. Construction and Building Materials, 165, $792-800$. https://doi.org/10.1016/j.conbuildmat.2018.01.078.

Zhen, G., Zhou, H., Zhao, T., \& Zhao, Y. (2012). Performance appraisal of controlled low-strength material using sewage sludge and refuse incineration bottom ash. Chinese Journal of Chemical Engineering, 20(1), 80-88. https://doi.org/10.1016/S1004-9541(12)60366-8 